\title{
DRYING AND ENERGY RECOVERY OF SLUDGE
}

\author{
CORNEL SAVA ${ }^{\mathrm{a},{ }^{,}, \text {ELENA MARIA PICĂ }}{ }^{\mathrm{a}}$
}

\begin{abstract}
This paper presents some of the results of research on the introduction of the operation of drying sludge from wastewater treatment in treatment plants. Graphical representations of the experimentally determined values demonstrate the possibility of continuing the process of decreasing the humidity of dehydrated sludge, by mechanical means.

Sludge drying is presented as a simple operation that can be easily introduced into the sludge treatment process.

The second part of the paper presents a machine that could be executed with relatively small amounts in each treatment plant in order to achieve the drying of dehydrated sludge.

The paper presents characteristics of dehydrated sludges in Cluj and Sălaj counties as well as chemical analyzes performed on dehydrated sludges.

In conclusion, the paper argues that dry sludge can be removed from the waste and turned into a material resource.
\end{abstract}

Keywords: wastewater, wastewater treatment plants, sludge, waste, drying tunnel, dry mud, resource.

\section{INTRODUCTION}

Wastewater collected through sewer systems built in the perimeter of urban and rural settlements is led to treatment plants. The concentration of substances in wastewater in $\mathrm{mg} / \mathrm{dm}^{3}$ or $\mathrm{g} / \mathrm{m}^{3}$, is the amount of substances contained in the unit volume. Mineral or organic substances are found in wastewater. The connections that exist in the wastewater have a decisive role in decantability. In the mixture formed using drinking water for hygienic or industrial purposes, water is found in several forms:

Free water not associated with solid particles: interstitial water, located in free spaces inside flakes and adherent water - which has adhered to the surface of solid particles,

Bound water is water that has interacted with the cells of living organisms.

a Technical University of Cluj-Napoca, Building Services Engineering Department, Blvd. December 21, no. 128-130, 400604, Cluj-Napoca, România

Corresponding author: sava.cornel47@yahoo.com 
The bonds that are established between water molecules and the cells of living organisms can be [1, 2]:

- Biological - intercellular water that represents a part of the cells linked by molecular forces in a stable phase,

- Chemical - intercellular water which is a part of the molecular crystal lattice also in a stable phase;

- Physical - in colloids the connection is maintained by the surface stresses present at the boundary between phases.

The stability of colloidal systems is ensured by factors that prevent particle agglomeration. The electrostatic repulsive forces are strong enough to prevent their agglomeration. In order for these particles to become large enough to be separated by sedimentation, a chemical treatment is required to cancel the interactions between the colloidal particles and water, making it possible to agglomerate them and deposit them on the decanter raft. The formation of aggregates begins with the proximity of particles, by reducing electrostatic repulsive forces.

\section{RESULTS AND DISCUSSION}

Coagulation can be considered as a first step in the wastewater treatment process. As a result of the deposition of coagulated particles on the decanter scrap in the treatment plants, results sludge. The resulting amount of sludge is directly related to the number of inhabitants and the specific water consumption. A consumption of 180 to 200 liters of water per inhabitant, attests to an increased urban comfort. The quantities of sludge resulting in several wastewater treatment plants in Cluj and Zalău counties are presented in Table 1.

Table 1. Sludge quantities in wastewater treatment plants

\begin{tabular}{|c|c|c|}
\hline Town & $\begin{array}{c}\text { The amount of sludge } \\
\text { [t/day] }\end{array}$ & $\begin{array}{c}\text { The amount of sludge } \\
\text { [t/year }\end{array}$ \\
\hline Cluj Napoca & 70 & 7154 \\
\hline Dej & 6.6 & 506 \\
\hline Zalău & 10 & 913 \\
\hline Gherla & 6 & 438 \\
\hline
\end{tabular}

Moisture or water content varies depending on the nature of the sludge (mineral or organic) and the treatment stage from which it comes. In wastewater treatment plants, sludge can come from three sources [3, 4]:

1. The primary sludge is fresh sludge from the primary settling tank, has a gray color and contains household waste which decomposes easily, 
2. Secondary sludge is sludge from the secondary settling tank after precipitation of activated sludge and separation of excess sludge. Excess secondary sludge has a brown color,

3. Precipitation sludge is sludge resulting from the chemical precipitation of phosphorus.

Sludge from wastewater treatment plants is collected and treated in complex systems to remove moisture. The primary sludge contains to a large extent solid organic matter and has the consistency of a dense liquid, with a water content between $93 \%$ and $97 \%$.

The secondary sludge usually has a dry matter concentration of $0.7 \%$ and $7 \mathrm{Kg} / \mathrm{m}^{3}$, respectively.

The removal of water from the sludge is an important objective aimed at bringing the sludge to a state in which it can be stored and prepared for further processing.

In the treatment plants in Romania, the sludge dehydration takes place in the dehydration units where filter type equipment (belt press and polymer dosing) or centrifugal type equipment is used.

Table 2 presents the performances obtained in several treatment plants in Cluj and Sălaj counties.

Table 2. Treatment plants performances

\begin{tabular}{|c|c|}
\hline Town & Humidity reduction (MS) \\
\hline Cluj Napoca & $28 \%$ \\
\hline Dej & $21 \%$ \\
\hline Zalău & $25 \%$ \\
\hline Gherla & $20 \%$ \\
\hline
\end{tabular}

Figure 1 shows the results obtained after drying the samples in spaces without ventilation, at a temperature of $50{ }^{\circ} \mathrm{C}$.

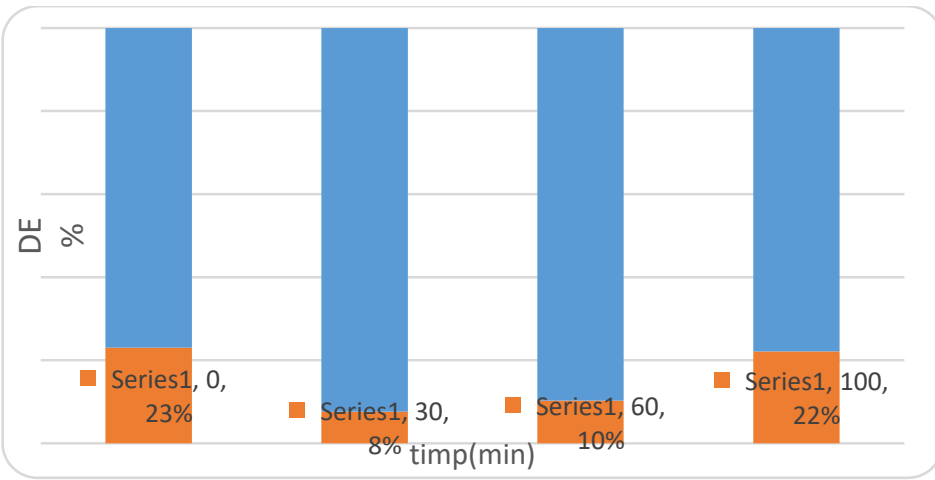

Figure 1. Sample drying results at $50{ }^{\circ} \mathrm{C}$ without ventilation 
In Figure 2 we present the results of drying the samples under the same time conditions, but at a temperature of $100^{\circ} \mathrm{C}$.

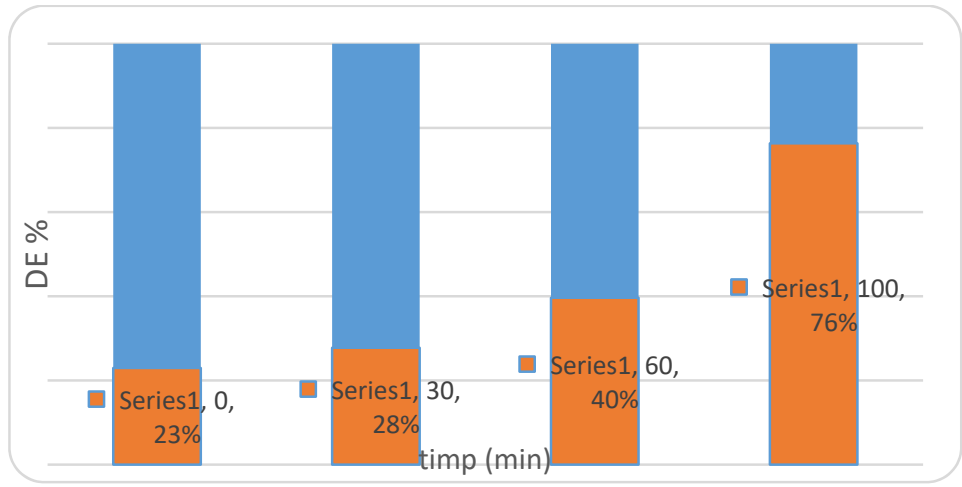

Figure 2. Drying results at $100^{\circ} \mathrm{C}$ without ventilation

Doubling the temperature in an unventilated space has an insignificant influence on the degree of evaporation by comparison with the degree of evaporation obtained at $50^{\circ} \mathrm{C}$ in a ventilated space.

The degree of evaporation obtained in unventilated space at 100 ${ }^{\circ} \mathrm{C}$ is comparable to the degree of evaporation obtained with only $50{ }^{\circ} \mathrm{C}$ in a ventilated space.

The experiment was done to show the importance of proper ventilation of the drying space [5].

Figure 3 shows the results of drying the samples at $50^{\circ} \mathrm{C}$ in ventilated spaces.

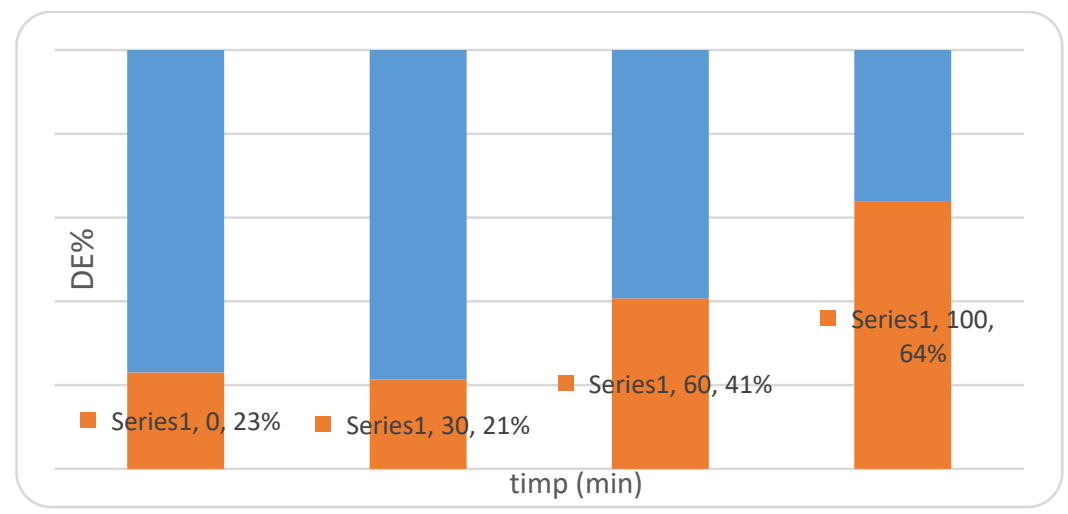

Figure 3. Samples drying results at $50{ }^{\circ} \mathrm{C}$ with ventilation 
Ventilation of the drying space significantly increases the degree of evaporation, even in low temperature conditions.

Figure 4 shows the results of drying the samples under the same conditions, but at a temperature of $100{ }^{\circ} \mathrm{C}$.

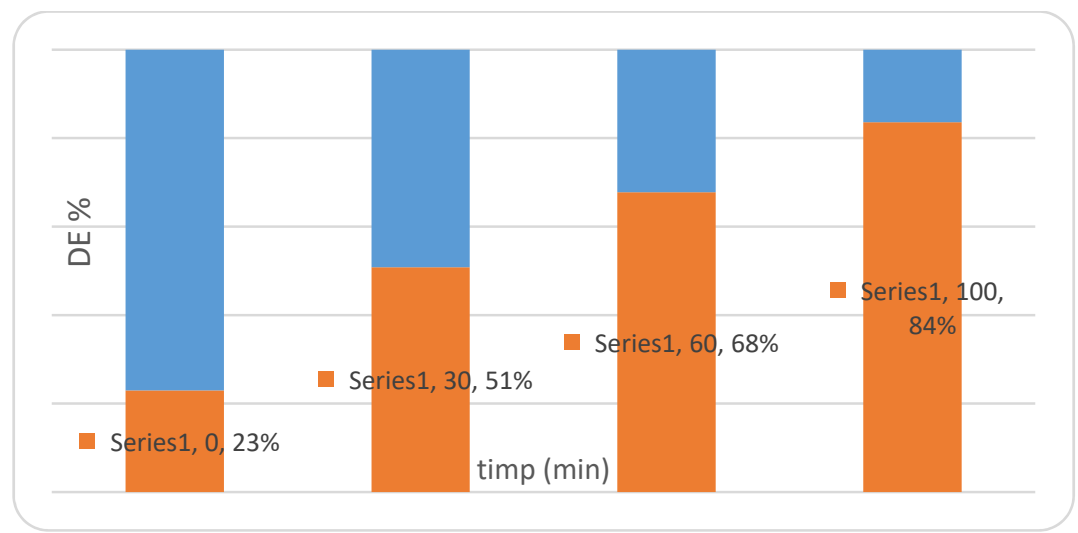

Figure 4. Drying results at $100{ }^{\circ} \mathrm{C}$ with ventilation

Doubling the temperature in ventilated areas significantly increases the degree of evaporation.

This experiment was selected as the starting point for the construction of a drying tunnel.

The values used in the construction of the graphical representations presented in fig.1-4 were obtained by introducing the results in equation (1) [6]:

where:

$$
D E=\left(G_{p i}-G_{p u}\right) / G_{p i} \times 100
$$

$\mathrm{DE}=$ degree of evaporation;

$\mathrm{G}_{\mathrm{pi}}=$ weight of the sample before drying;

$\mathrm{G}_{\mathrm{pu}}=$ weight of the dry sample

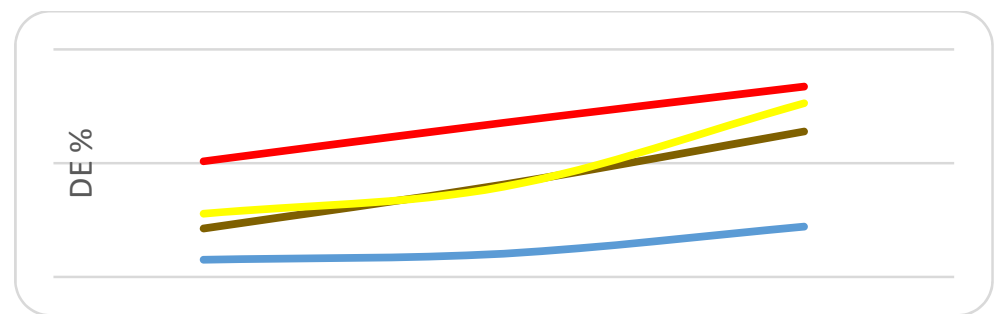

Figure 5. Graphical representation of the drying results of the ventilated and non-ventilated samples:- $100^{\circ} \mathrm{C}$ with ventilation, $-100^{\circ} \mathrm{C}$ without ventilation, $-50{ }^{\circ} \mathrm{C}$ with ventilation, $-50^{\circ} \mathrm{C}$ without ventilation. 
Figure 5 represent a comparison of the results by graphical representation, in temperature-time coordinates, in ventilated enclosures and unventilated enclosures.

The graphic representation explicitly shows the superiority of the ventilated drying spaces and the high efficiency for the temperature of $100{ }^{\circ} \mathrm{C}$.

In support of the use of dry sludge as a resource, it is presented in tables no. 3 and 4 chemical elements contained in 7 samples of dehydrated sludge.

In Table 3 we present the results determined on 3 samples of dehydrated sludge and Table 4 shows the results for 4 samples of dehydrated sludge.

Tables 3 and 4 presents the results of chemical analyses performed in accordance with the regulations mentioned in the section Method of analysis. The determinations were performed on 7 different samples, to determine the elements contained in the dehydrated sludge. The percentage in which these elements are found in dehydrated sludge is very important for choosing the destination of dehydrated and dry sludge [7-9].

Table 3. Chemical analyses performed on sludge samples

\begin{tabular}{|c|c|c|c|c|c|c|}
\hline \multirow{2}{*}{\begin{tabular}{|l|} 
Determined \\
parameters
\end{tabular}} & \multirow[t]{2}{*}{ UM } & \multicolumn{3}{|c|}{ Sample } & \multirow[t]{2}{*}{ Analysis method } & \multirow{2}{*}{ 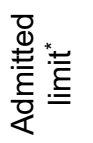 } \\
\hline & & 1 & 2 & 3 & & \\
\hline Dry substance (DS) & $\%$ & 17 & 11.82 & 18.77 & STAS 12586-87 & \\
\hline $\begin{array}{l}\text { Organic substance } \\
\text { (OS) }\end{array}$ & $\%$ & 82.5 & 77.24 & 83.15 & STAS 12586-87 & \\
\hline Phosphorus & $\mathrm{mg} / \mathrm{kg} \mathrm{ds}$ & 4864 & 4828.7 & 20567 & $\begin{array}{c}\text { SR ISO } \\
11263 / 1998 \\
\end{array}$ & \\
\hline Cadmium & $\mathrm{mg} / \mathrm{kg} \mathrm{ds}$ & 1.356 & 1.387 & 1.755 & $\begin{array}{l}\text { SR EN ISO } \\
11047 / 1999 \\
\end{array}$ & 10 \\
\hline Copper & $\mathrm{mg} / \mathrm{kg} \mathrm{ds}$ & 171.7 & 133.3 & 131.9 & $\begin{array}{l}\text { SR EN ISO } \\
11047 / 1999\end{array}$ & 500 \\
\hline Nickel & $\mathrm{mg} / \mathrm{kg} \mathrm{ds}$ & 22.35 & 23.26 & 16.64 & $\begin{array}{l}\text { SR EN ISO } \\
11047 / 1999\end{array}$ & 100 \\
\hline Zinc & $\mathrm{mg} / \mathrm{kg} \mathrm{ds}$ & 467.3 & 496.2 & 439.9 & $\begin{array}{l}\text { SR EN ISO } \\
11047 / 1999\end{array}$ & 2000 \\
\hline Chromium & $\mathrm{mg} / \mathrm{kg} \mathrm{ds}$ & 24.83 & 26.16 & 27.52 & $\begin{array}{l}\text { SR EN ISO } \\
11047 / 1999 \\
\end{array}$ & 500 \\
\hline Lead & $\mathrm{mg} / \mathrm{kg} \mathrm{ds}$ & 38.75 & 28.26 & 81.68 & $\begin{array}{l}\text { SR EN ISO } \\
11047 / 1999 \\
\end{array}$ & 300 \\
\hline Calcium & $\%$ & 1.206 & 1.376 & 0.7065 & EPA 7000B & - \\
\hline Potassium & $\%$ & 1.008 & 0.670 & 0.4781 & EPA 7000B & - \\
\hline
\end{tabular}

"according to OM no. 344/708/2004 
Table 4. Chemical analyzes performed on samples of dehydrated sludge

\begin{tabular}{|c|c|c|c|c|c|c|c|}
\hline \multirow[t]{2}{*}{ Determined parameters } & \multirow[t]{2}{*}{ Unit } & \multicolumn{4}{|c|}{ Sample } & \multirow{2}{*}{$\begin{array}{l}\text { Analysis } \\
\text { method }\end{array}$} & \multirow{2}{*}{ 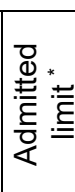 } \\
\hline & & 1 & 2 & 3 & 4 & & \\
\hline Total nitrogen & $\%$ (ds) & 5.19 & 4.93 & 5.82 & 3.13 & $\begin{array}{c}\text { ISO } \\
\text { 13878:1998 }\end{array}$ & - \\
\hline Arsenic & $\mathrm{mg} / \mathrm{kg} \mathrm{ds}$ & 5.10 & 5.40 & 2.0 & 4.15 & $\begin{array}{l}\text { SR EN ISO } \\
11885: 2009\end{array}$ & 10 \\
\hline Cobalt & $\mathrm{mg} / \mathrm{kg} \mathrm{ds}$ & 7.79 & 2.0 & 5.0 & 4.61 & $\begin{array}{l}\text { SR EN ISO } \\
11885: 2009\end{array}$ & 50 \\
\hline Mercury & $\mathrm{mg} / \mathrm{kg} \mathrm{ds}$ & 0.32 & 0.80 & 0.47 & 0.80 & $\begin{array}{l}\text { SR EN ISO } \\
11885: 2009\end{array}$ & 5 \\
\hline $\begin{array}{l}\text { AOX (adsorbable } \\
\text { halogenated organic } \\
\text { compounds) }\end{array}$ & $\mathrm{mg} / \mathrm{kg} \mathrm{ds}$ & 0.94 & 4.64 & 15.95 & 2.26 & $\begin{array}{l}\text { SR EN ISO } \\
8562: 2005\end{array}$ & 500 \\
\hline $\begin{array}{l}\text { PAH (polycyclic } \\
\text { aromatic hydrocarbons) }\end{array}$ & $\mathrm{mg} / \mathrm{kg} \mathrm{ds}$ & 0.092 & 0.147 & 0.012 & 0.008 & $\begin{array}{l}\text { SR EN ISO } \\
17993:: 2004\end{array}$ & 5 \\
\hline
\end{tabular}

"according to OM no. 344/708/2004

Chemical analyses performed on dehydrated sludge show that the heavy metal content cannot be influenced by dehydration and drying.

By drying at a temperature above $80^{\circ} \mathrm{C}$, eggs and bacilli that are dangerous to crops can be removed. For heavy metal content it is necessary to make laboratory determinations to be made available to those who are to approve the use of dry sludge for fertilizing agricultural land. The beneficial elements for fertilization are represented by the content of phosphorus, nitrogen, and potassium.

The chemical analyzes presented in Tables 3 and 4 show that dehydrated and dry sludge can be used without posing any danger to soils or to humans. All chemical elements are within the limits allowed by current legislation.

\section{EXPERIMENTAL SECTION}

Dehydrated sludges at the percentages of solid substance that were presented in Table 2, are stored in a buffer silo from which the supply can be made for their thermal recovery. The sludge can be transported by pumping or conveyors. Drying technology can allow drying between $75 \%$ and $90 \%$, depending on the destination of the dried sludge. The drying tunnel is a mixed conduction / convection type machine, in which the dehydrated sludge 
dries in a single pass. At the exit, the sludge can be in the form of granules or cakes. The sludge is heated by a fluid that transfers heat without coming into direct contact. For the drying tunnel to be effective, as shown in laboratory experiments, it must ensure the evacuation of evaporated water. The evacuation of water vapor can be done with a process gas, blown in the direction of movement of the sludge subjected to drying. The shape of the inner surfaces of the dryer must be so designed as to prevent the accumulation of sludge inside the machine.

Gas emissions to the atmosphere must be considered when constructing the drying tunnel. The gases produced inside the drying tunnel are fully recovered and passed through a condensing system. The liquid obtained is analyzed in the laboratory and the toxic elements neutralized [10].

Dry sludge is an easy product to use in many industries. Drying at high temperatures reduces the infectious potential of sludge, making it possible to use it in agriculture. If you opt for the energy recovery of sludge by incineration, the dry sludge is already ready for combustion. The sludge drying operation is an important step in diversifying the ways of capitalizing on this treatment product, which is now an important source of pollution [11-13].

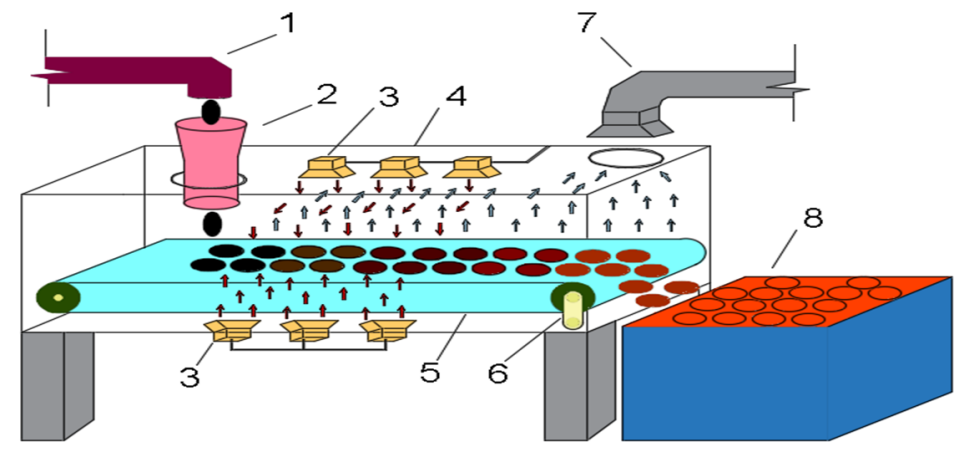

Figure 6. Dehydrated sludge drying tunnel

1.- Dehydrated sludge food basket; 2. - Mud steering funnel; 3. - Heating and ventilation system; 4. - Drying tunnel; 5. - Conveyor belt; 6 . - Band drive drum; 7. - Vapor collection system; 8. - Dry sludge unloading container.

The equipment shown in Figure 6 is an original proposal that can achieve the drying of sludge as established experimentally. The drying tunnel allows adjustments and adaptations for all the main elements involved in the phenomenon of water evaporation. Thus, the degree of ventilation, drying time and working temperature can be easily adjusted [14]. 
Drying of dehydrated sludge is an operation that allows them to be removed from the category of environmentally hazardous waste and introduced into the category of resources usable in many areas.

Dry sludge becomes easy to store and is not dangerous for the environment [15].

\section{CONCLUSIONS}

Water removal by mechanical means is limited by the performance of the equipment. To further remove water from dehydrated sludge, this paper proposes an original method of drying sludge after it has come out of the dehydration equipment.

During the research, conditions like those encountered in the natural environment were created. Experiments have been created that can accurately highlight the factors involved in the complex phenomenon of water evaporation from dehydrated sludge.

To verify the method, samples were taken from the dehydrated sludge and weighed and dried. The samples were dried in different drying environments, namely ventilated drying spaces, and unventilated drying spaces.

Another direction of research was to establish the relationship between the time required for drying and the degree of evaporation. The samples were dried at different temperatures to determine how the temperature influences evaporation.

In all cases, the degree of evaporation was the difference in weight between the sample subjected to drying and the same dry sample.

For use, the dried sludge is subjected to chemical determinations showing the composition in favourable elements for use and toxic elements that do not allow its use as a resource.

\section{ACKNOWLEDGMENTS}

We thank Prof. Dr. Eng. Ovidiu Nemeș for the advice and encouragement that made it possible for this paper to be offered for consultation to those interested.

\section{REFERENCES}

1. B. Lyes, A. Patricia, L. Angélique, Review on fundamental aspect of application of drying process to wastewater sludge, Renewable and Sustainable Energy Reviews, Elsevier, 2013, 30, 29-43.

2. M. Henze, P. Harremoes, J. Jes LaCour Jansen, E. Arvin, Wastewater treatment: biological and chemical processes, Springer Berlin Heidelberg, Germany, 2001, $1-422$. 
3. T. Rusu, Technologies and equipment for water treatment and purification, U.T. Pres, Cluj-Napoca, România, 2008, Vol. I.

4. D. Mamais, D. Jenkins, Water Res., 1993, 27, 195-197.

5. P. Tudor, D. Florin, H. Anca, Ventilation and air conditioning installations, U.T. Pres, Cluj-Napoca, România, 2010, Vol. 1, 1-348.

6. G. Olsson, B. Newell, Wastewater treatment systems: modelling, diagnosis and control, IWA publishing, London, United Kingdom, 1999, 1-750.

7. B. Rao, L. Cao, J. Agric. Eng., 2012, 28, 184-188.

8. A. Reyes, M. Eckholt, F.Troncoso, G. Efremov, J. Drying Technol., 2004, 22, 35-50.

9. B. Lyes, Renewable and Sustainable Energy Reviews, 2012, 16, 1061-1073.

10. I. Vădan, A. C. Cziker, Modern energy conversion systems, U.T. Pres, ClujNapoca, România, 2017, 1-505.

11. "ÖWAV-Arbeitsausschuss "Thermische Behandlung und Verwertung", 2006, 1-4.

12. Horst Müller, ÖWAV-Klärschlammtagung, 2018, 1-60.

13. B.C O'Kelly, J. Air Waste Manag. Assoc., 2005, 765.

14. V.L. Mathioudakis, A.G. Kapagiannidis, E. Athanasoulia, V.I. Diamantis, P. Melidis, A. Aivasidis, Desalination, 2009, 248 (1-3), 733-739.

15. I. Leonard, M. Dumitru, V. Nicoleta, D. M. Motelică, T. Veronica, Methodology for using urban sludge in agriculture, Ed. Solness, Timișoara, România, 2007, pp 1-193. 